\title{
PENERAPAN SNP KABUPATEN/KOTA TAHUN 2017 PADA SARANA PRASARANA DINAS KEARSIPAN DAN PERPUSTAKAAN KUBU RAYA
}

\author{
Elin Maulinda, Sahidi \\ Program Studi Diploma 3 Perpustakaan FKIP Untan Pontianak \\ Email: elinmaulinda@untan.com
}

\begin{abstract}
This study discusses then application of the 2017 Regency/Municipal SNP the Archives and Libraries Office of Kubu Raya. The method used is qualitative research, data collection techniques in the form of direct observation, documentation, and interviews. There are 4 informants who have special abilities in the field of libraries. The results showed that the location of the Archives and Library Office of Kubu Raya Regency was in a location that was not strategic and had no direction, and was behind the Education Office and Health Office so it was difficult to see. The area of the Kubu Raya Regency Library is not adequate because it is not in accordance with the National Library Standards. In the Regulation of the Head of the National Library of the Republic of Indonesia Number 8 of 2017 concerning National Standards for Regency/City Libraries for infrastructure, a minimum building area of $0.008^{2}$ per capita is calculated, which if calculated the library building area is $4,635 \mathrm{~m}^{2}$ per capita. Meanwhile, the building area of the Office of Archives and Library of Kubu Raya Regency is $8 x$ $24 \mathrm{~m}^{2}$. Constraints experienced by the Kubu Raya Regency Library are library building and budget problems.
\end{abstract}

Keywords: Facilities and Infrastructure, National Standards of Libraries, Public Libraries.

\section{PENDAHULUAN}

Menurut Peraturan Kepala Perpusnas Nomor 8 Tahun 2017 Perpustakaan adalah lembaga yang menyelenggarakan karya tulis, karya cetak, dan/atau karya rekam secara profesional dengan sistem standar untuk memenuhi kebutuhan pendidikan, penelitian, pelestarian, informasi dan rekreasi bagi pengguna. Secara umum perpustakaan umum adalah jenis perpustakaan yang didirikan oleh masyarakat umum dan dibiayai oleh masyarakat itu sendiri, baik secara langsung (swadaya) maupun tidak langsung, seperti melalui pajak (Saleh, 2014).

Perpustakaan umum kabupaten/kota adalah perpustakaan yang menjadi faktor unit pelayanan di setiap masyarakat, termasuk Perpustakaan Kabupaten/Kota yang berada di wilayah masyarakat guna memudahkan masyarakat dalam mencari berbagai informasi, karena perpustakaan umum kabupaten/kota menyediakan berbagai sumber informasi yang dibutuhkan masyarakat sebagai sumber informasi. sarana pembelajaran sepanjang hayat, tanpa memandang usia, ras, agama, 
status sosial ekonomi, dan jenis kelamin. Secara umum perpustakaan dapat dibedakan menjadi beberapa macam, ialah Nasional, Umum, Sekolah/Madrasah, Perguruan Tinggi serta Khusus. Setiap operasional perpustakaan harus mengikuti standar perpustakaan. Pada tahun 2017, Perpusnas RI mengeluarkan Standar Perpusnas untuk setiap jenis perpustakaan, salah satunya adalah SNP Kabupaten/Kota.

Aturan kepala Perpusnas RI No 8 tahun 2017 tentang SNP Kabupaten/Kota. Peraturan tersebut memuat standar koleksi perpustakaan, standar sarana dan prasarana perpustakaan, standar layanan perpustakaan, standar staf perpustakaan, standar pengelolaan perpustakaan, dan standar pengelolaan perpustakaan. Perpustakaan Kabupaten/Kota ialah perpustakaan daerah yang berperan seperti perpustakaan pengawas, perpustakaan referensi, perpustakaan simpanan, perpustakaan penelitian, dan perpustakaan pelestarian yang berkedudukan di kabupaten/kota.

Kantor arsip dan perpustakaan kabupaten Kubu Raya termasuk dalam jenis perpustakaan umum. Perpustakaan Daerah Kubu Raya berkewajiban menyediakan informasi yang ada di perpustakaan sehingga dapat menjadi tempat belajar sepanjang hayat khususnya bagi masyarakat Kabupaten Kubu Raya. Agar dapat menjalankan fungsinya dengan baik, Perpustakaan Daerah Kabupaten Kubu Raya harus mampu menyediakan sarana dan prasarana yang dapat mewadahi masyarakat dalam memenuhi kebutuhan informasi. Sesuai dengan amanat aturan kepala Perpusnas RI No 8 tahun 2017, perpustakaan daerah Kubu Raya harus melaksanakan peraturan perpustakaan sesuai dengan Standar Perpustakaan Nasional.

Dari hasil penelitian menunjukkan bahwa letak Kantor Arsip dan Perpustakaan Kubu Raya terletak pada lokasi yang tidak strategis serta tidak mempunyai penunjuk arah arah bangunan perpustakaan, juga di belakang Dinas Pendidikan. Perkantoran dan Dinas Kesehatan sehingga sulit dilihat oleh masyarakat. Luas gedung perpustakaan Kabupaten Kubu Raya masih kurang memadai karena tidak sesuai dengan Standar Perpustakaan Nasional. Dalam Peraturan Kepala amanat aturan kepala Perpusnas RI No 8 tahun 2017 tentang SNP Kabupaten/Kota tentang Sarana Prasarana sekurang-kurangnya memiliki luas bangunan sebesar $0,008 \mathrm{~m} 2$ per kapita.

Secara umum menurut Badrus Suryadi dan Susi Rahmawati (2018) fasilitas adalah semua benda yang dapat dijadikan sebagai alat dan bahan untuk mencapai tujuan. Fasilitas lebih ditujukan untuk benda bergerak seperti meja, komputer, telepon, dan sebagainya. Infrastruktur adalah segala sesuatu yang menjadi penunjang utama tercapainya suatu proses (business, builder, project). Infrastruktur lebih ditujukan pada benda-benda tidak bergerak seperti gedung, ruangan, dan tanah.

Berdasarkan pengamatan langsung yang dilakukan peneliti, terdapat ketidaksesuaian sarana dan prasarana yang tersedia di Kantor arsip dan Perpustakaan Kubu Raya dengan Peraturan Kepala Perpustakaan Nasional RI nomor 8 Tahun 2017, untuk itu peneliti didorong untuk mengkaji bagaimana implementasi Standar Perpustakaan Nasional tentang Sarana Prasarana pada Kantor Kearsipan dan Perpustakaan Kubu Raya.

Tujuan umum dari penelitian ini ialah bagaimana penerapan Standar Nasional Perpustakaan Kabupaten/Kota Tahun 2017 tentang Sarana Prasarana di Kantor Kearsipan dan Perpustakaan Kubu Raya yaitu untuk mengetahui penerapan standar sarana dan prasarana di lingkungan Kubu Raya. Kantor Arsip dan Perpustakaan Kabupaten serta untuk mengetahui kendala penerapan standar. sarana prasarana di kantor arsip dan perpustakaan kubu raya.

\section{METODE PENELITIAN}

Penelitian ini menggunakan metode penelitian deskriptif kualitatif dengan teknik pengumpulan data berupa observasi langsung, wawancara serta dokumentasi. Mengenai narasumber dalam penelitian ini ada 4 orang yang memiliki kemampuan khusus di bidang perpustakaan. Objek penelitian adalah Kantor Arsip dan Perpustakaan Kubu Raya.

\section{HASIL DAN PEMBAHASAN Hasil}

Penelitian ini dilaksanakan di Kantor Arsip dan Perpustakaan Kubu Raya dengan judul penelitian "Penerapan SNP Kabupaten/Kota Tahun 2017 Pada Sarana Prasarana Dinas Kearsipan Dan Perpustakaan 
Kubu Raya". Dalam penelitian ini, peneliti mendeskripsikan penerapan standar infrastruktur menurut aturan kepala Perpusnas RI No 8 tahun 2017 dan kendala dalam penerapannya. Data dalam penelitian ini diperoleh melalui pendekatan kualitatif deskriptif dengan teknik pengumpulan data berupa observasi, wawancara dan dokumentasi.

\section{Pembahasan}

Untuk mengetahui permasalahan mengenai Penerapan Standar Nasional Perpustakaan Kabupaten/Kota Tahun 2017 tentang Sarana Prasarana pada Kantor Arsip dan Perpustakaan Kubu Raya sehingga peneliti dapat mengetahui penerapan standar sarana dan prasarana serta kendala dalam aplikasi mereka.

\section{Penerapan Standar Nasional Perpustakaan Kabupaten / Kota Nomor 8 Tahun 2017 di Dinas Kearsipan dan Perpustakaan Kubu Raya.}

Di Perpustakaan Umum Kubu Raya penerapan Standar Perpustakaan Nasional sebagian sudah dilaksanakan, namun pada bagian infrastruktur belum memenuhi standar nasional perpustakaan. Seharusnya Perpustakaan Umum Kabupaten memiliki gedung sendiri, sedangkan Perpustakaan Kabupaten Kubu Raya tidak memiliki gedung sendiri karena masih menyatu dengan Dinas Kearsipan Kabupaten Kubu Raya.

\section{Lokasi atau tanah}

Menurut Menurut aturan kepala Perpusnas RI No 8 tahun 2017 mengenai SNP Kabupaten/Kota bahwa perpustakaan harus memiliki lokasi yang strategis sehingga mudah dijangkau oleh penduduk. Sedangkan perpustakaan Kubu Raya tidak memiliki letak yang strategis dan tingkat pemanfaatannya oleh masyarakat rendah. Perpustakaan umum seharusnya berfungsi sebagai penunjang penyelenggara pendidikan masyarakat, namun perpustakaan yang tidak memiliki letak yang strategis dan tidak mudah dijangkau dapat menjadi kendala bagi perpustakaan. Perpustakaan Umum Kabupaten Kubu Raya belum memenuhi standar nasional untuk bagian infrastruktur perpustakaan.

Informasi ini sesuai dengan hasil wawancara dengan Kepala Divisi Perpustakaan Umum Kabupaten Kubu Raya pada tanggal 23 Agustus 2021 bahwa "lokasi perpustakaan harus strategis dan mudah dijangkau oleh masyarakat, masyarakat kabupaten Kubu Raya. perpustakaan berada di lokasi yang strategis dan mudah dijangkau tetapi sulit dilihat, karena letaknya yang berada di belakang dinas kesehatan dan pendidikan sehingga sulit untuk dilihat atau diketahui oleh masyarakat".

Menurut aturan kepala Perpusnas RI No 8 tahun 2017 mengenai SNP Kabupaten/Kota, letak perpustakaan berada pada lokasi yang strategis serta mudah dijangkau oleh masyarakat serta lahan perpustakaan yang berada di bawah kepemilikan dan/atau kewenangan Pemerintah Kabupaten/Kota yang status hukumnya jelas. Berdasarkan pengamatan, Perpustakaan Kubu Raya terletak di tempat yang strategis serta mudah dijangkau tetapi sulit untuk dilihat dan diketahui bahwa di lokasi tersebut terdapat perpustakaan, dan lahan perpustakaan sudah berada di bawah kepemimpinan atau kewenangan dari Pemerintah.

2. Gedung Perpustakaan

Salah satu peran bangunan (Gedung) perpustakaan ialah sebagai tempat penyimpanan koleksi. Gedung perpustakaan merupakan gedung yang seluruhnya diperuntukan untuk semua kegiatan perpustakaan. Sebaiknya gedung perpustakaan berdiri sendiri, sedangkan Perpustakaan Umum Kabupaten Kubu Raya belum memiliki gedung sendiri dan masih terintegrasi dengan Dinas Kearsipan Kabupaten Kubu Raya.

Informasi ini sesuai dengan hasil wawancara dengan Kepala Divisi Perpustakaan Umum Kabupaten Kubu Raya pada Senin 23 Agustus 2021 bahwa "Perpustakaan Umum Kubu Raya masih belum memenuhi SNP khususnya dalam infrastruktur mengapa dikatakan tidak melengkapi SNP, karena perpustakaan umum Kabupaten Kubu Raya ini belum memiliki gedung sendiri dan hanya memiliki ruang perpustakaan, sedangkan gedung tersebut masih menyatu dengan Dinas Kearsipan Kubu Raya dan memiliki luas ruangan 8 x $24 \mathrm{~m} 2$ ”. 
Menurut Menurut aturan kepala Perpusnas RI No 8 tahun 2017 mengenai SNP Kabupaten/Kota, luas gedung perpustakaan paling kurang $0,008 \mathrm{~m} 2$ per kapita dan bersifat permanen. yang memungkinkan pembangunan fisik berkelanjutan dan bangunan perpustakaan melengkapi standar konstruksi, teknologi, suasana, kenyamanan, keselamatan, kesehatan, keamanan, kelengkapan, keindahan, efektif dan efisien. Dan gedung perpustakaan dilengkapi dengan tempat parkir, fasilitas umum, dan fasilitas khusus.

Hasil pantauan gedung Perpustakaan Umum Kabupaten Kubu Raya belum memenuhi Standar Perpustakaan Nasional pada bagian infrastruktur karena gedung Perpustakaan Umum Kabupaten Kubu Raya hanya memiliki luas bangunan 8 x $24 \mathrm{~m} 2$ (192 m2). parkir selesai. Jumlah penduduk atau per kapita wilayah Kubu Raya tahun 2019 data melalui Dinas Kependudukan serta Catatan Sipil daerah Kubu Raya menyebutkan jumlahnya sebanyak 579.331 jiwa dengan laju pertumbuhan yang meningkat sebesar $1,47 \%$. Jumlah anggota komunitas laki-laki adalah 293.643 orang dan perempuan 285.688 orang. Jika dihitung berdasarkan standar perpustakaan nasional, maka luas bangunan yang dibutuhkan adalah:

$=$ jumlah per kapita (penduduk) $\mathrm{x}$ luas ruang berdasarkan SNP

$=579.331 \times 0,008 \mathrm{~m} 2$ per kapita

3. Ruang Perpustakaan

Ruang perpustakaan merupakan tempat dimana pustakawan dan pengguna berinteraksi dan berkomunikasi untuk mencari suatu koleksi. Ruang perpustakaan juga memegang peranan penting dimana kenyamanan dalam ruangan diberikan oleh pustakawan kepada penggunanya. Informasi ini sesuai dengan hasil wawancara dengan Bapak Hendri selaku staf tamu di Perpustakaan Umum Kabupaten Kubu Raya pada tanggal 10 September 2021 bahwa "Perpustakaan Umum Kabupaten Kubu Raya terdiri dari area baca, area koleksi dan area ruang kerja, tetapi ruang mana yang digabungkan menjadi satu yang membuat pengguna tidak efektif".

Menurut aturan kepala Perpusnas RI No 8 tahun 2017 mengenai SNP
Kabupaten/Kota, ruang perpustakaan paling sedikit harus memiliki ruang koleksi, ruang baca, dan ruang tenaga kerja yang tertata secara efektif., efisien dan estetis. Masingmasing perpustakaan mempunyai ruang menyimpan koleksi, akses data, serta fasilitas layanan perpustakaan. Berdasarkan pengamatan bahwa ruang Perpustakaan Umum Kabupaten Kubu Raya masih belum mencukupi untuk Standar Perpustakaan Nasional, karena di ruang Perpustakaan Kabupaten Kubu Raya ruangan-ruangan tersebut digabungkan menjadi satu dengan area koleksi, area membaca, area kerja dan area koleksi anak, sehingga sulit untuk bergerak.

4. Saran Perpustakaan

Fasilitas perpustakaan merupakan peralatan dasar dan penunjang agar perpustakaan dapat berjalan dengan baik. Fasilitas perpustakaan di Perpustakaan Umum Kabupaten Kubu Raya sudah dapat dikatakan sebagian memenuhi Standar Perpustakaan Nasional. Informasi ini sesuai dengan hasil wawancara dengan Kepala Perpustakaan Umum Kabupaten Kubu Raya pada hari Senin, 23 Agustus 2021 bahwa "Fasilitas perpustakaan di Perpustakaan Umum Kabupaten Kubu Raya dikatakan sudah memenuhi sebagian perpustakaan nasional. meskipun ada beberapa yang belum terpenuhi, dan untuk sarana pengaksesan informasi hanya memiliki satu komputer, tidak memiliki lemari dan loker yang dapat dikunci”.

Menurut Menurut aturan kepala Perpusnas RI No 8 tahun 2017 mengenai SNP Kabupaten/Kota. Sedangkan fasilitas akses informasi sekurang-kurangnya berupa perabot dan alat temu kembali objek perpustakaan serta informasi, fasilitas ruang pelayanan perpustakaan sekurangkurangnya berupa perlengkapan dan kelengkapan yang diimbangi dengan berbagai macam pelayanan perpustakaan, seperti perabot kerja 1 set/pengguna, fasilitas penyimpanan 1 set/pengguna, peralatan multimedia 1 set/per pengguna, dan peralatan lainnya 1 set/perpustakaan. Berdasarkan pengamatan, terdapat beberapa fasilitas di Perpustakaan Kabupaten Kubu Raya yang belum terpenuhi, seperti akses informasi, lemari yang dapat dikunci, dan 
laci penyimpanan pengunjung/pengguna, sedangkan fasilitas lain yang sudah ada seperti meja baca, rak koleksi, kursi, meja kerja dan AC.

Tabel 1. Sarana Prasarana Perpustakaan Kubu Raya

\begin{tabular}{cccc}
\hline No. & Fasilitas & Jumlah & \multicolumn{2}{c}{ Keterangan } \\
\cline { 3 - 4 } & & Baik $\begin{array}{c}\text { Kurang } \\
\text { Baik }\end{array}$ \\
\hline 1. & AC & 1 & $\checkmark$
\end{tabular}

2. Kipas $\quad 1 \quad \checkmark$

Angin

\begin{tabular}{llll}
\hline 3. & Komputer & 1 & $\checkmark$ \\
& & & \\
\hline 4. & Printer & 1 & $\checkmark$
\end{tabular}

5. $\begin{array}{lll}\text { Rak } & 3 & \checkmark\end{array}$

Referensi

6. $\begin{array}{lll}\text { Rak } & 29 & \checkmark\end{array}$

Koleksi

7. Kursi 12

Baca

8. Meja $\quad 2 \quad \checkmark$

Baca

9. Kursi $3 \quad \checkmark$

Petugas

$\begin{array}{llll}\text { 10. } & \text { Meja } & 3 & \checkmark \\ & \text { Petugas } & & \end{array}$

11. Meja 1

Baca

Lesehan

12. Loker

5. Fasilitas perpustakaan umum yang lengkap Perpustakaan Umum Kabupaten Kubu Raya harus melengkapi fasilitas yang ada di ruang perpustakaan. Berdasarkan pantauan, Perpustakaan Umum Kabupaten Kubu Raya masih memiliki fasilitas yang belum terpenuhi, seperti area membaca, area koleksi anak, area tenaga kerja, dan area koleksi yang digabungkan dalam satu ruangan, tidak hanya itu, seperti loker dan lemari penyimpanan. yang bisa dikunci, belum ada. Berdasarkan hasil wawancara dengan Kepala Perpustakaan Umum Kabupaten Kubu Raya pada hari Senin, 23 Agustus 2021 bahwa "fasilitas di ruang perpustakaan umum Kabupaten Kubu Raya dikatakan baik dan terdapat ruang baca yang cukup".

Perpustakaan umum kabupaten Kubu Raya memiliki fasilitas yang baik dan ruang baca yang cukup, hanya dalam satu ruangan yang terdiri dari berbagai area. Selain itu, fasilitas di ruang perpustakaan ini seperti rak buku, meja baca, kursi baca, meja kerja dan AC.

Kendala dalam penerapan standar nasional perpustakaan pada sarana dan prasarana menurut peraturan kepala perpustakaan Nasional Republik Indonesia nomor 8 tahun 2017 di Perpustakaan Kubu Raya.

Berdasarkan wawancara peneliti dengan nara sumber ditemukan bahwa permasalahan yang dihadapi oleh Kantor Kearsipan dan Perpustakaan Kabupaten Kubu Raya dalam mengimplementasikan Standar Perpustakaan 
Nasional pada sarana dan prasarana sesuai dengan Peraturan Kepala Perpusnas Indonesia No 8 Tahun 2017 yang belum memiliki gedung sendiri dan ketersediaan dana.

1. Gedung perpustakaan

Masalah gedung perpustakaan menjadi kendala utama yang dimiliki Kantor Arsip dan Perpustakaan Kabupaten Kubu Raya dalam menerapkan standar yang ada. Gedung perpustakaan masih terintegrasi dengan Layanan Arsip. Perpustakaan umum tersebut sebelumnya telah mengajukan permohonan pembangunan gedung sendiri, namun belum mendapat persetujuan dari ACC. Informasi ini sesuai dengan hasil wawancara dengan nara sumber pada Rabu, 10 November 2021, bahwa "tidak ada gedung sendiri. Telah diusulkan untuk membangun gedung perpustakaan mereka sendiri tetapi belum di ACC".

2. Anggaran

Anggaran perpustakaan adalah laporan sumber keuangan yang disisihkan untuk memperlancar kegiatan di perpustakaan. Informasi ini sesuai dengan hasil wawancara dengan nara sumber pada Rabu 03 November 2021 bahwa "Ya, anggaran menjadi kendala utama dalam penerapan Standar Perpustakaan Nasional, khususnya di Sarana Prasarana, untuk memenuhi Standar Perpustakaan Nasional Memerlukan cukup anggaran yang besar sementara anggaran saat ini lebih fokus pada Operasional dan kegiatan rutin, belum ada yang benar-benar fokus pada Sarana dan Prasarana."

Berdasarkan hasil wawancara diatas, Perpustakaan Umum Kabupaten Kubu Raya ini masih kekurangan anggaran dalam memenuhi standar dibidang sarana dan prasarana khususnya. Anggaran yang ada saat ini masih berfokus ke kegiatan operasional perpustakaan. Kegiatan operasional adalah bentuk pengelolaan menyeluruh serta optimal pada aspek tenaga kerja, barang-barang, atau faktor produksi lain yang bisa dijadikan sebagai produk barang dan jasa yang lazim diperdagangkan. Adapun contoh kegiatan operasional perpustakaan yaitu dibidang pelayanan dan pengembangan koleksi.
"Dana. Besaran dana dinas dianggarkan dari APBD dimana yang menentukan besaran dana dinas, bukan dinas itu sendiri, patokan dana yang dianggarkan untuk dinas sudah ada susah ditentukan. Kebutuhan sapras sudah dianggarkan oleh dinas, namun keputusan akhir disetujui atau tidak bukan dinas yang menentukan, sapras dihitung tiap tahun, tapi untuk memenuhi kebutuhan, namun sering kali hanya untuk mengganti sapras yang sudah ada namun rusak. Kenapa tidak diajukan baru atau menambah? Karena keterbatasan ruang, belum punya gedung sendiri. Namun sapras sesuia SNP yang pertama ya harus sediakan tempat dulu untuk menyimpan barang-barangnya kan. Nah untuk membah ruang dana yang dibutuhkan banyak". hasil tersebut berdasarkan wawancara nara sumber pada 10 November 2021 anggaran menjadi kendala kedua bagi Perpustakaan Umum Kabupaten Kubu Raya.

Besaran anggaran Perpustakaan Kabupaten Kubu Raya berasalkan dari APBD yang sudah ditentukan jumlahnya. Penganggaran setiap perpustakaan berdasarkan kebutuhan yang dirancang dan ditentukan oleh perpustakaan itu sendiri, namun hal ini masih perlu persetujuan apakah akan dianggarkan atau tidak. Hal ini, juga terjadi pada Perpustakaan Umum Kabupaten Kubu Raya yang mana sudah membuat dan merancang anggaran dalam mengganti atau menambah sarana dan prasarana dalam menunjang kegiatan perpustakaan, namun masih perlu keputusan akhir apakah disetujui atau tidak.

Sesuai Aturan Kepala Perpusnas RI Kabupaten/Kota No 8 Tahun 2017 tentang SNP Kabupaten/Kota. Bahwa dana perpustakaan adalah 1. Perpustakaan mengelola rancangan dana saling berkaitan sesuai melalui fungsi perpustakaan. 2. Menyiapkan anggaran yang mengacu pada desain strategis dan desain perpustakaan kerja/progja. 3. Dana perpustakaan secara rutin berasal dari APBD. 4. Dana perpustakaan berasal dari sumber lain yang bukan bersifat wajib. 5. Pimpinan perpustakaan bertanggung jawab untuk merekomendasikan, mengadministrasikan, dan menggunakan anggaran. 
Menurut Mulyadi (dalam Ahmad, 2020), anggaran adalah suatu rencana kegiatan yang dinyatakan secara kuantitatif yang diperhitungkan dalam bagian standar moneter dan ukuran lain yang terdiri dari jangka waktu kurang lebih satu tahun. Jadi, anggaran memiliki satuan atau besaran yang dapat diukur secara kuantitatif sesuai dengan rencana yang telah ditetapkan. Anggaran ini dikeluarkan setiap tahun baik untuk perpustakaan maupun lembaga lainnya.

\section{KESIMPULAN DAN SARAN Simpulan}

Penerapan SNP Kabupaten/Kota tentang Sarana Prasarana sesuai aturan Kepala Perpusnas RI No 8 Tahun 2017. Sarana dan Prasarana Perpustakaan Umum Kubu Raya belum memadai untuk menunjang kinerja Perpustakaan Nasional RI. Standar Perpustakaan. Dari hasil penelitian menunjukkan bahwa letak Kantor Arsip dan Perpustakaan daerah Kubu Raya berada pada tempat yang tidak strategis serta tidak memiliki arah menuju gedung perpustakaan, juga berlokasi di belakang Dinas Pendidikan dan Dinas Kesehatan sehingga sulit dilihat oleh masyarakat. Luas gedung perpustakaan Kabupaten Kubu Raya masih kurang memadai karena tidak sesuai dengan Standar Perpustakaan Nasional.

Dalam Peraturan Kepala Perpustakaan Nasional Republik Indonesia Nomor 8 Tahun 2017 tentang Standar Nasional Perpustakaan Kabupaten/Kota tentang Sarana dan Prasarana sekurang-kurangnya memiliki luas bangunan sebesar $0,008 \mathrm{~m} 2$ per kapita yang apabila dihitung paling tidak luas bangunan perpustakaan adalah $4.635 \mathrm{~m} 2$ per kapita. Sedangkan luas bangunan Arsip dan Perpustakaan Kabupaten Kubu Raya adalah 8 x $24 \mathrm{~m} 2 \quad(192 \mathrm{~m} 2)$ dengan luas ruang perpustakaan $8 \times 12 \mathrm{~m} 2(96 \mathrm{~m} 2)$, hal ini dikarenakan masih dibawah satu bangunan atap sebagai Dinas Kearsipan Kabupaten Kubu Raya. Area baca, area koleksi dan area tenaga kerja terintegrasi ke dalam perpustakaan Kabupaten Kubu Raya, hal ini dapat mengganggu kinerja pustakawan dan ketidaknyamanan pengguna. Untuk saat ini, tenaga perpustakaan Kabupaten Kubu Raya telah mengajukan rencana penambahan sarana dan prasarana perpustakaan, seperti pembangunan gedung perpustakaan.

Kendala yang dialami oleh Perpustakaan Umum Kubu Raya adalah masalah gedung perpustakaan yang menjadi kendala utama dalam penerapan standar yang ada. Anggaran menjadi kendala kedua bagi perpustakaan ini. Besaran anggaran tersebut berasal dari APBD yang telah ditentukan. Penganggaran masingmasing perpustakaan didasarkan pada kebutuhan yang dirancang dan ditentukan oleh perpustakaan itu sendiri, namun hal ini masih perlu persetujuan apakah akan dianggarkan atau tidak.

\section{Saran}

Menurut hasil penelitian yang ditemukan, peneliti mengusulkan supaya Dinas Kearsipan dan Perpustakaan Umum Kubu Raya membuat papan nama perpustakaan sebelum memasuki kawasan resmi. Diharapkan Kantor Arsip dan Perpustakaan Kabupaten Kubu Raya dapat menyiasati aturan ruang perpustakaan yang kurang memadai sehingga dapat meningkatkan kenyamanan baik pengguna maupun pustakawan itu sendiri.

\section{DAFTAR RUJUKAN}

Ahmad Nurhadi dan Aidil Amin Effendy. (2020). Penganggaran Perusahaan. Tangerang Selatan: UNPAM (Universitas Pamulang). From: http://eprints.unpam.ac.id/8799/1/SMJ0 293_PENGANGGARAN\%20PERUSA HAAN.pdf diakses pada tanggal 21 November 2021

Peraturan Kepala Perpustakaan Nasional Republik Indonesia Nomor 8 Tahun 2017. Standar Nasional Perpustakaan Kabupaten/Kota. From: https://jdih.perpusnas.go.id/file_peratura n/Perka_8_2017_SNP_Perpustakaan_K ab_Kota_Salinan.pdf diakses pada tanggal 25 Juni 2021.

Saleh, A. R. (2014). Manajemen Perpustakaan. Tangerang Selatan: Universitas Terbuka. Sugiyono. (2009). Memahami Penelitian Kualitatif. Bandung: Alfabeta.

Suryadi, Badrus., S. R. (2018). Otomatisasi Tata Kelola Sarana dan Prasarana. Jakarta: Gramedia Widia Sarana Indonesia. From: https://www.google.co.id/books/edition/ 
Otomatisasi_Tata_Kelola_Sarana_dan_ Prasa/TBIVEAAAQBAJ?hl=id\&gbpv= $1 \& d q=$ inauthor:\%22Badrus+Suryadi, $+S$ .Pd.,M.M.+dan+Sulis+Rahmawati,+S.P d.\%22\& printsec $=$ frontcover diakses pada tanggal 24 Juni 2021.

https://kuburayakab.go.id/tentang/demografis 
